\title{
Endocannabinoids in the Dentate Gyrus
}

\author{
Charles J. Frazier ${ }^{1,2}$ \\ ${ }^{1}$ Department of Pharmacodynamics, University of Florida, College of Pharmacy \\ ${ }^{2}$ Department of Neuroscience, University of Florida, College of Medicine
}

\begin{abstract}
Recent years have produced rapid and enormous growth in our understanding of endocannabinoidmediated signalling in the CNS. While much of the recent progress has focused on other areas of the brain, a significant body of evidence has developed that indicates the presence of a robust system for endocannabinoid-mediated signalling in the dentate gyrus. This chapter will provide an overview of our current understanding of that system based on available anatomical and physiological data.
\end{abstract}

\section{Introduction}

Both chronic and acute use of cannabis (marijuana) produces a wide array of physiological, cognitive, and analgesic effects in humans that have been widely recognized for centuries. The active ingredient in marijuana, delta-9-tetrahydrocannabinol ( $\Delta^{9}$-THC), was first identified in 1964 (Gaoni and Mechoulam, 1964); the first primary cannabinoid receptor in the CNS (CB1) was identified and cloned in 1990 (Matsuda et al., 1990; Howlett et al., 1990), and the principal endogenous ligands, arachidonoylethanolamide and 2-arachidonylglycerol, were identified soon thereafter (Devane et al., 1992; Sugiura et al., 1995).

Efforts to understand the neurophysiological consequences of $\mathrm{CB} 1$ receptor activation received an enormous boost in 2001 with the discovery that endogenous cannabinoids (ECs) act as retrograde signaling molecules in a phenomenon known as depolarization induced suppression of inhibition (DSI) (Wilson and Nicoll, 2001; Ohno-Shosaku et al., 2001). As originally described by Pitler and Alger in hippocampal pyramidal cells (1992), and by Marty in cerebellar Purkinje cells (Llano et al., 1991), DSI is a form of short term synaptic plasticity whereby depolarization of a single neuron results in transient inhibition of GABAergic afferents to that same neuron. A principal role for endogenous cannabinoids in DSI is indicated by the fact DSI is blocked by CB1 antagonists, occluded by CB1 receptor agonists, and absent in CB1 ${ }^{-/-}$ animals (Wilson et al., 2001; Wilson and Nicoll, 2001; Varma et al., 2001; Ohno-Shosaku et al., 2001; Kreitzer and Regehr, 2001a; Yoshida et al., 2002). The retrograde nature of the ECmediated signalling was originally (and most simply) indicated by failure of depolarization induced EC release (or bath application synthetic agonists) to inhibit responses to local application of exogenous GABA, despite effectively reducing evoked responses. This and other physiological data is strongly supported by an array of immunohistochemical studies that indicate prominent expression of CB1 receptors both presynaptically and on GABAergic terminals (for general review see Freund et al., 2003, and below).

Although it has only been a short time since these landmark studies, EC-dependent DSI governed by fundamentally similar mechanisms has now been identified in numerous other

Contact Information: Name: Charles J. Frazier, Ph.D., Phone: 352-392-3447, Fax: 352-392-9187, cjfraz@ufl.edu, Address: University of Florida, JHMHC Box 100487, 1600 S.W. Archer Road, Gainesville, FL 32610, R01 DA019576-02. 
brain areas including the amygdala, substantia nigra, basal ganglia, neocortex, brainstem, and recently, in both granule cells and mossy cells of the dentate gyrus (Yanovsky et al., 2003; Trettel and Levine, 2003; Bodor et al., 2005; Zhu and Lovinger, 2005; Isokawa and Alger, 2005; Mukhtarov et al., 2005; Engler et al., 2006; Hofmann et al., 2006). Cumulatively, these findings highlight what is now the obviously broad significance of EC-mediated retrograde signalling in modulating inhibitory transmission in the CNS, but nevertheless, represent only a small percentage of recent advances. For example, it is now clear that cannabinoid receptors are expressed on many glutamatergic terminals as well. Accordingly, depolarization induced EC-mediated inhibition of excitation (DSE) has now been described in the cerebellum (Kreitzer and Regehr, 2001b), ventral tegmental area (Melis et al., 2004a; Melis et al., 2004b), hypothalamus (Di et al., 2005), amygdala (Domenici et al., 2006), and in the hippocampus (Ohno-Shosaku et al., 2002b), where the role of ECs in modulating Schaffer collateral inputs to CA1 pyramidal cells remains a particularly active area of investigation (Hajos and Freund, 2002; Hoffman et al., 2005; Takahashi and Castillo, 2006; Katona et al., 2006). Further, efforts to understand the role of postsynaptic metabotropic glutamate receptors in EC release have proven instrumental in identifying EC-mediated long term depression (LTD) in a number of areas. At present, both heterosynaptic and homosynaptic forms of EC-dependent LTD have been described, affecting both GABAergic and glutamatergic synapses respectively (Robbe et al., 2002; Marsicano et al., 2002; Chevaleyre and Castillo, 2003; Hoffman et al., 2003). While presynaptic expression still seems to be the norm in this form of EC-dependent synaptic plasticity, there has even been a recent example of EC-mediated, mGluR dependent LTD in the cerebellum that is expressed postsynaptically (Safo and Regehr, 2005). Given the extensive nature of EC-mediated effects on synaptic transmission, it should perhaps not come as a surprise that fascinating metaplastic roles for ECs are also now coming to light. For example, Castillo and colleagues have recently and elegantly demonstrated that EC-mediated LTD can lower the threshold for traditional NMDA-dependent LTP in spatially confined parts of the CA1 pyramidal cell dendritic tree (Chevaleyre and Castillo, 2004).

These types of findings are mentioned here in brief simply to underscore our growing appreciation for the enormous breadth of EC-dependent signalling in CNS physiology, and to highlight the extremely rapid nature of recent progress. In my view, this trend shows no sign of slowing. In fact, in this chapter, I will attempt to make the case that the dentate gyrus is an area of significant interest, and strong potential, for this field; albeit one that has received comparatively little attention to date. In making that argument I will highlight a significant body of existing evidence clearly indicating the presence of a robust system for EC-dependent signaling in the dentate gyrus, I will review the growing list of studies that reveal specific neurophysiological consequences of EC-dependent signalling at identified synapses in the dentate, and I will cover recent work suggesting several novel roles for EC signalling (from neuroprotection to neurogenesis) in which the dentate may be an area of particular interest. Potential future directions for some of this work will also be discussed. For a broader overview of specific roles for ECs in CNS physiology the interested reader is referred to any number of recent and outstanding reviews (Schlicker and Kathmann, 2001; Wilson and Nicoll, 2002; Alger, 2002; Freund et al., 2003; Chevaleyre et al., 2006; Marsicano and Lutz, 2006).

\section{A brief overview of the endocannabinoid system}

There are currently two known cannabinoid receptors: the CB1 receptor, cloned in 1990 (Matsuda et al., 1990), and the CB2 receptor, identified three years later (Munro et al., 1993). Both receptors are classic metabotropic receptors coupled to $\mathrm{G}_{\mathrm{i} / \mathrm{o}}$. Of these, the CB1 receptor appears to be intimately involved in mediating most central effects of endogenous cannabinoids. It is among the most prominently expressed metabotropic receptors in the mammalian CNS, with overall expression levels approaching that of ionotropic receptors for glutamate and GABA. Particularly high levels of CB1 expression are found in hippocampus 
(including the dentate gyrus), cortex, cerebellum, and basal ganglia (Herkenham et al., 1991a; Herkenham et al., 1991c; Tsou et al., 1998a). This distribution is consistent with well recognized effects of cannabinoids on movement and memory. The CB2 receptor by contrast, has been reported in the CNS only in striatum and cerebellum (Skaper et al., 1996; Van Sickle et al., 2005), but is far more abundant in the immune system where it is thought be involved in regulation of both immune function and inflammatory responses (for review see Berdyshev, 2000; De et al., 2000). Since the CB2 receptor is believed to be absent in the dentate, it will not be reviewed further here.

There are likely several endogenous ligands for the CB1 receptor, of which two have been particularly well characterized to date: arachidonoylethanolamide (anandamide, abbreviated AEA) and 2-arachidonoyl-glycerol (2-AG). Both of these ligands are fatty acid derivatives, although they differ significantly in terms of their synthetic pathway. AEA is thought to be synthesized by phospholipase $\mathrm{D}$ induced hydrolysis of a lipid precursor, $\mathrm{N}$-arachidonoyl phosphatidylethanolamine (N-arachidonoyl-PE) (Di Marzo et al., 1994; Cadas et al., 1997; Di Marzo et al., 1999). One of the primary immediate precursors for synthesis of 2-AG, by contrast, appears to be diacylglycerol, which is produced from phosphatidylinositol by phospholipase C, and subsequently converted to 2-AG by diacylglycerol lipase (Stella et al., 1997; Piomelli, 2003).

Because both AEA and 2-AG are membrane permeant, conventional vesicular release mechanisms are implausible. Thus, regulation of EC-mediated signalling is likely to depend principally on regulation of the synthetic pathways described above, on uptake from the extracellular space, and on subsequent breakdown. These processes also differ somewhat between AEA and 2-AG. Synthesis of AEA is increased significantly by rapid increases in intracellular calcium concentration (that reach low $\mu \mathrm{M}$ levels), such as occur with membrane depolarization. The calcium dependence of AEA production is tied to the fact that availability of N-arachidonoyl-PE depends heavily on the activity of a highly calcium-dependent enzyme, $\mathrm{N}$-acyltransferase, which is capable of producing $\mathrm{N}$-arachidonoyl-PE from phosphatidylethanolamine (Di Marzo et al., 1994; Cadas et al., 1996; Piomelli, 2003).

While it is clear that increases in intracellular calcium can also increase production of 2-AG through a PLC and DAG dependent pathway (Stella et al., 1997), the overall story here is somewhat more complicated. For example, in some systems calcium dependent production of 2-AG is likely to be significantly enhanced if the calcium influx occurs coincident with synaptic activation of certain metabotropic receptors (notably metabotropic glutamate receptors and/or muscarinic acetylcholine receptors) capable of activating a calcium-dependent isoform of phospholipase C (Hashimotodani et al., 2005; Maejima et al., 2005). On the other hand, there also appear to be metabolic routes through which metabotropic receptors can promote largely calcium-independent production of 2-AG (Varma et al., 2001; Maejima et al., 2001; OhnoShosaku et al., 2002a; Fukudome et al., 2004; Ohno-Shosaku et al., 2005).

Once AEA has reached the extracellular space, uptake is mediated by a fast, selective, saturable, temperature-dependent, and thus apparently carrier-mediated process (Beltramo et al., 1997; Hillard et al., 1997; Piomelli et al., 1999). Subsequently, AEA is rapidly broken down to arachidonic acid and ethanolamine by fatty acid amide hydrolase (FAAH), an enzyme that has an expression pattern in the CNS that closely corresponds to that of the CB1 receptor (Hillard et al., 1995; Cravatt et al., 1996; Egertova et al., 1998; Piomelli et al., 1999; Deutsch et al., 2002). The corresponding story is again more complicated for 2-AG. While it is clear that the anandamide transporter can also facilitate uptake of 2-AG, and that FAAH can also break it down, it is too early to rule out the possibility of an additional transport mechanism for 2-AG, and it is clear that at least one other major route for breakdown, in this case mediated by monoglyceride lipase, is available (Dinh et al., 2002). 
Activation of metabotropic $\mathrm{CB} 1$ receptors located primarily on presynaptic terminals may be coupled to adenylyl cyclase, or directly to either $\mathrm{Ca}^{2+}$ or $\mathrm{K}^{+}$conductances, and is typically (but perhaps not exclusively) observed to inhibit calcium dependent release of neurotransmitter. The general consensus is that such activation of endogenous CB1 receptors typically occurs through retrograde transmission of endocannabinoids synthesized postsynaptically, and further that 2-AG and/or AEA are likely to be the retrograde messengers in most if not all forms of EC-mediated retrograde signalling identified to date. It is interesting to note that 2-AG is present in brain at concentrations approximately 200 -fold greater than AEA, although this may simply reflect a more central role in lipid metabolism and not necessarily a similarly dominant role in retrograde signalling (Sugiura et al., 1995; Stella et al., 1997). For interesting and recent discussion of the relative roles of 2-AG and AEA in retrograde signalling see Chevaleyre et al (2006).

While this represents a brief and general summary of the EC system as currently understood in the brain (including the dentate) it is important to reiterate that this field is advancing rapidly. Significant advances in our conceptions of this system are certainly possible, and perhaps even probable. One area where our knowledge is currently developing at a rapid pace concerns CB1 receptor-mediated modulation of glutamatergic transmission (see below). Further, it is likely that additional sites of EC action will be identified which may include currently uncloned CBlike receptors and/or conventional non-CB receptors not previously associated with EC action. Thus it seems likely that our understanding of the possible modulatory effects of ECs on synaptic transmission in the CNS will only broaden with time. A more extensive discussion of the molecular aspects of EC signalling is available in a number of other reviews (Di Marzo and Deutsch, 1998; Lutz, 2002; Piomelli, 2003; Sugiura et al., 2006).

\section{Markers of the EC system in the dentate gyrus}

\section{CB1 receptor expression in the dentate gyrus: initial findings indicate prominent role in GABAergic neurons}

Early efforts to map the distribution of putative $\mathrm{CB}$ receptors in brain were hindered by the fact that they relied largely on radiolabeled derivatives of $\Delta^{9}$-THC that had generally poor affinity for the receptors and a strong tendency to partition into biological membranes (Harris et al., 1978; Roth and Williams, 1979; Thomas et al., 1992). However, in 1991 two landmark studies capitalized on the favorable properties of a synthetic CB1 agonist, CP55,940, to provide one of the first complete surveys of putative cannabinoid receptor binding sites in the CNS (Herkenham et al., 1991a; Herkenham et al., 1991b). These studies demonstrated that the molecular layer of the dentate gyrus was among the most intensely labeled areas in the rat brain. Comparatively low to moderate levels of ${ }^{3} \mathrm{H}-\mathrm{CP} 55,940$ binding were also reported in the hilus, with only sparse labeling over the granule cell layer. Interestingly, these studies also reported differential binding of ${ }^{3} \mathrm{H}-\mathrm{CP} 55,940$ along the septo-temporal axis of the hippocampus, with denser binding on the dorsal (septal) end. These findings, which were reported from rat brain, were largely consistent with later studies using the same radioligand in human (Glass et al., 1997).

While the original studies with ${ }^{3} \mathrm{H}-\mathrm{CP} 55,940$ represented a significant advance in their day, it is noteworthy that they were completed at about the same time that the CB1 receptor was isolated and cloned (Matsuda et al., 1990). That feat enabled two additional approaches to the study of CB1 receptor expression and distribution. The first to be employed was in situ hybridization for CB1 mRNA (Mailleux et al., 1992; Mailleux and Vanderhaeghen, 1992; Matsuda et al., 1993; Marsicano and Lutz, 1999). In general, these studies noted high levels of CB1 mRNA in a subpopulation of cells in the subgranular region of the hilus, where ${ }^{3} \mathrm{H}-$ CP55,940 was low to moderate, with comparatively less concentrated expression of CB1 mRNA in the molecular layer, where ${ }^{3} \mathrm{H}-\mathrm{CP} 55,940$ binding had been intense. This differential 
distribution between CB1 mRNA expression and ${ }^{3} \mathrm{H}-\mathrm{CP} 55,940$ binding was the basis for one of the first arguments that functional CB1 expression may be relegated largely to processes distal from the soma.

The second major advance enabled by cloning of the CB1 receptor was the immunohistochemical characterization of receptor distribution in the CNS. This technique offered several significant advantages over earlier efforts. First, because the initial antibodies employed were targeted to specific amino acid sequences on the N-terminal of the cloned CB1 receptor, they offered significantly greater specificity than earlier radioligand binding studies. Second, the higher resolution of immunohistochemical techniques allowed the first detailed examination of CB1 expression at the subcellular level. Third, the eventual application of elegant dual-labeling immunohistochemical techniques allowed simultaneous analysis of CB1 expression and cell phenotype. As such, our current understanding of CB1 expression and distribution in the CNS depends heavily on these techniques, and results relevant to the dentate will be reviewed in some detail below.

The first immunohistochemical studies of CB1 distribution in the CNS clearly demonstrated intense immunoreactivity in the molecular layer of the dentate gyrus (Pettit et al., 1998; Tsou et al., 1998a; Katona et al., 1999). Consistent with early binding studies, the intensity of this signal was reported to be highest in the inner third of the molecular layer, and on the septal end of the hippocampus (Tsou et al., 1998a). However, based on the greater resolution of these techniques, it now became apparent that this area specifically contained many CB1immunoreactive nerve fibers, but very few labeled cell bodies. By contrast, intensely immunoreactive neuronal cell bodies were identified in the hilus, just below the granule cell layer. These cells were reported to represent as much as $62 \%$ of all CB1-immunoreactive cell bodies in the dentate, and had characteristic pyramidal morphology, with a single primary dendrite that often extended without branching through the granule cell layer towards the molecular layer (Tsou et al., 1998a; Katona et al., 1999). The remaining CB1-positive cell bodies were located largely in the hilus and exhibited a variety of morphologies.

The subsequent application of dual-labeling immunohistochemical techniques represented a major advance in this area, as it allowed the determination that the vast majority of CB1immunoreactive cell bodies were also positive for CCK. Specifically, between 80 and $95 \%$ of all CCK-positive cell bodies in the dentate were reported to also be CB1-positive, with a comparably high percentage of CB1-positive cells being CCK-positive. In stark contrast, virtually none of the parvalbumin-positive basket cells expressed CB1 (Katona et al., 1999; Tsou et al., 1999). Further examination of these results at the electron microscopic level indicated cellular expression of CB1 was largely or exclusively confined to cytoplasmic organelles, while surface expression of CB1 was very high on CCK-positive axon terminals that were often clustered around principal cell somas and proximal dendrites (Katona et al., 1999). Although these particular observations were originally made primarily in hippocampal cells in CA1 and CA3, it now seems reasonable to predict that surface expression of CB1 on GABAergic neurons in the dentate may also be restricted to nerve terminals. This hypothesis is consistent with the differential distribution of ${ }^{3} \mathrm{H}-\mathrm{CP} 55,940$ binding and in situ hybridization described earlier, and is also strongly supported by a study from the Freund lab the following year that specifically identified CB1-positive axon terminals in the hilus (Acsady et al., 2000). Although this study did not directly perform dual-labeling experiments for both CB1 and CCK, it did make the striking observation that both CB1-positive and (in separate experiments) CCK-positive terminals displayed very similar and yet highly unusual target selectivity. Specifically they found these terminals made abundant synaptic contacts on the soma and proximal dendrites of the GluR2/3 and CGRP-positive hilar mossy cells, but largely avoided both parvalbumin and substance $\mathrm{P}$ (and thus also CCK)-immunoreactive interneurons in the hilus. 
Cumulatively, the data described so far clearly indicates prominent expression of CB1 receptors in the dentate, particularly on presynaptic terminals of CCK-positive interneurons, many of which have cell bodies located in the subgranular zone. The specific distribution of CB1-positive terminals further suggests a likely role for CB1 activation in regulating GABAergic transmission to both granule cells and hilar mossy cells. Nevertheless the apparent absence of CCK and CB1positive terminals making synaptic contact with other basket cells clearly distinguishes hilar circuitry from that in other hippocampal subfields, and may hold clues to understanding the unique physiology of this area. While the vast majority of the work described above was completed in either Sprague-Dawley or Wistar rats, the basic features of CB1 expression in the dentate described so far appear to be largely conserved in gray mouse lemur, primate, and human brain (Ong and Mackie, 1999; Katona et al., 2000; Harkany et al., 2005). Further, although much of this work has relied on the N-terminal antibodies to the CB1 receptor that are identical or similar to the one originally developed by Tsou et al. (1998a), key features of this expression pattern have also been observed using antibodies that target intracellular sites on the C-terminal end of the CB1 receptor (Hajos et al., 2000; Egertova and Elphick, 2000). Nevertheless, at this juncture it is important to emphasize that the data as summarized above do not represent the full picture with respect to likely sites of EC action in the dentate. Our current understanding of this topic with respect to glutamatergic systems is reviewed below.

\section{CB1 receptor expression in the dentate gyrus: emphasis on glutamatergic neurons}

Compared to the results summarized above, the question of $\mathrm{CB} 1$ receptor expression by glutamatergic neurons has so far been a contentious one. This is particularly true in areas CA1 and CA3 where apparent expression of low levels of CB1 mRNA in pyramidal neurons as indicated by in situ hybridization generally has not been easy to reconcile with the apparent lack of CB1 immunoreactivity on glutamatergic cell bodies or axon terminals as indicated by immunohistochemical techniques. This discrepancy has been made all the more acute by divergent reports from a number of outstanding labs regarding the physiological effects of ECs on glutamatergic transmission in the Schaffer collateral pathway (Hajos and Freund, 2002; Hoffman et al., 2005; Takahashi and Castillo, 2006; Katona et al., 2006). However, in general, the current details of this debate are outside the scope of this review. The dentate gyrus has to a large extent been spared from a similar debate in part because, unlike in area CA1 and CA3, in situ hybridization tends to agree with both immunohistochemical analysis and early radioligand binding studies in suggesting that dentate granule cells are CB1-negative. Nevertheless, it would be inaccurate to say there have been no divergent results in this area at all. For example, a unique $\mathrm{N}$-terminal antibody targeting amino acids 83-91 of the CB1 receptor employed by Pettit et al. (1998) does label dentate granule cells, while the Tsou et al. (1998a) antibody that fails to label dentate granule cells in rats and humans has been reported to do so in non-human primates. While the precise reasons for these discrepancies in the dentate gyrus have still not been completely resolved, very recent work using novel C-terminal antibodies to CB1 has simultaneously reinforced the conclusion that dentate granule cells are CB1-negative, while elegantly demonstrating a potentially major role for EC signalling via the other glutamatergic cell type in the dentate, the hilar mossy cells.

The first of two significant reports in this area was from the lab of Tamas Freund (Katona et al., 2006). This study used a guinea pig anti-CB1 antibody originally characterized by Fukudome et al. (2004) that targets amino acids 443-473 on the C-terminal end of the protein. The pattern of CB1 immunoreactivity observed with this antibody had similar distribution to that previously reported, however the intensity of labeling was notably greater than had been observed previously, particularly in the inner third of the molecular layer. Further, upon examination of the results at the electron microscopic level it became clear that, in contrast to results with earlier antibodies, as many as $80 \%$ of asymmetrical (i.e. excitatory) synapses in 
the inner molecular layer, and 30-50\% of asymmetrical synapses in other layers were unambiguously positive for CB1. No differences in this pattern were observed between C57BL/ 6 and CD1 mice, and the authors noted that preliminary data suggests similar results will be obtained using this antibody in both rat and human hippocampus.

A second extremely recent study has reproduced and extended these findings using yet another unique antibody, in this case a goat anti-CB1 antibody targeting the C-terminal 77 amino acids of the protein (Monory et al., 2006). While providing other significant insights to be reviewed later in this chapter, this study confirms the presence of CB1-positive glutamatergic terminals in the inner third of the molecular layer by elegantly demonstrating clear immunohistochemical labeling for CB1 that is resistant to selective CB1 knockouts targeted specifically at GABAergic neurons, but reduced by selective CB1 knockouts targeting glutamatergic cells (for more on this technology, also see Marsicano et al., 2003). The observation that apparently glutamate-specific CB1 labeling was concentrated in the inner third of the molecular layer, combined with the observation that dentate granule cells continued to lack immunoreactivity for CB1 in all models, suggested the hypothesis that glutamate-specific CB1 labeling could be related to presynaptic expression on the axon terminals of hilar mossy cells. Consistent with that hypothesis, these authors further use dual-labeling in situ hybridization techniques to show strong co-localization of mRNA for CB1 and for the vesicular glutamate transporter type 1 (VGlutT1) both in the soma of hilar mossy cells and in presynaptic terminals forming asymmetric synaptic contacts in the inner molecular layer. These findings do not conflict with earlier work using other antibodies that indicated robust expression of CB1 on CCK-positive axon terminals in this area. Instead, they indicate additional expression of CB1 on glutamatergic terminals likely belonging to hilar mossy cells that was not previously detected. This is a striking conclusion by any measure, and I suspect it will have a significant impact on future work in this area. Nevertheless, the precise reasons that CB1 expression by glutamatergic terminals in the molecular layer was not detected earlier continue to be somewhat unclear. One likely possibility is that the $\mathrm{N}$-terminal antibodies generally employed in earlier work simply lack the sensitivity to detect lower levels of CB1 expression present on glutamatergic terminals. Another compatible possibility that has been raised, but to my knowledge not yet formally reported, is that there exists a 'CB1 receptor-interacting protein' that is exclusively expressed by excitatory cells and is capable of interfering with sites targeted by some of the earlier Cterminal antibodies (Niehaus et al. SFN Abstract 623.19, 2004).

\section{CB1 receptor expression in the dentate gyrus: co-expression with other receptor subtypes}

While a concerted effort has been made to characterize CB1 expression with respect to glutamatergic vs. GABAergic neurons and presynaptic vs. somatic expression as described above, some otherwise isolated reports have specifically examined co-expression of CB1 with other receptor subtypes. Noteworthy examples in the dentate include a report by Cristino et al. (2006) who used dual-labeling immunohistochemical techniques to suggest co-expression of both CB1 and the vanilloid receptor TRPV1 in many non-pyramidal bipolar neurons of the dentate, particularly in the molecular layer. Further, Morales and Backman (2002) used double labeling in situ hybridization techniques to demonstrate a strong co-localization of mRNA for both $\mathrm{CB} 1$ receptors and 5- $\mathrm{HT}_{3} \mathrm{~A}$ receptors in the subgranular interneurons of the dentate hilus. This result was generally consistent with Hermann et al. (2002) who also demonstrated colocalization of $\mathrm{CB} 1$ with $5-\mathrm{HT}_{1 \mathrm{~B}}$, and 5- $\mathrm{HT}_{3}$ receptors, and further noted the extent of coexpression was higher in neurons with high levels of CB1 mRNA. This study also was noteworthy in identifying co-expression of $\mathrm{CB} 1$ with $\mathrm{D} 2$ receptors throughout the dentate. These findings suggest the possibility of significant cross talk between several transmitter systems in regulating the activity of CCK-positive interneurons in the dentate. 


\section{Other Markers of the EC system in the dentate gyrus}

Although a few additional approaches have been employed, most efforts to demonstrate the presence of the EC system in the hippocampus and dentate gyrus without relying on detection of CB1 have focused on the two primary enzymes for degradation of AEA and 2-AG reviewed earlier: FAAH and monoglyceride lipase (MGL) respectively.

At this point, immunohistochemical studies targeting various areas on the C-terminal end of FAAH have indicated that expression is predominantly postsynaptic and largely confined to hippocampal principal cells and dentate granule cells (Tsou et al., 1998b; Romero et al., 2002; Egertova et al., 2003; Gulyas et al., 2004). This distribution is consistent with that reported for mRNA for FAAH (Thomas et al., 1997), and indicates that FAAH expression is largely restricted to neurons known to receive CB1-positive afferent inputs. The diffuse labeling for FAAH in outside the cell layers noted by Egertova et al. (2003) may be an artifact of tissue preparation, or as noted by the authors, could indicate an ability of principal cells to excrete FAAH into the extracellular space. Interestingly, Freund et al. (2004) has also noted that intracellular expression of FAAH was most often localized to the surface of organelles associated with calcium storage.

In contrast to the predominantly postsynaptic localization of FAAH, MGL appears to be expressed primarily presynaptically in both the hippocampus and dentate gyrus. Specifically, immunoreactivity for MGL has been identified on the mossy fiber axon terminals of dentate granule cells, as well as on the terminals of CA3 pyramidal cells and some interneurons (Gulyas et al., 2004). In contrast, absence of MGL immunoreactivity in certain areas of CA3 and the molecular layer noted in the same study suggested that CA1 and perforant path inputs are likely to lack this enzyme.

Another noteworthy technique in this area has been to examine the expression of diacylglycerol lipase (DAGL), a biosynthetic enzyme central to the production of 2-AG. Two very recent studies that were published almost simultaneously have both demonstrated that DAGL, as detected by immunohistochemical analysis using several different antibodies, is highly expressed by principal neurons in the hippocampus and granule cells (and likely mossy cells) of the dentate gyrus, and has further indicated that such expression is almost completely restricted to the head and neck of dendritic spines (Katona et al., 2006; Yoshida et al., 2006). Katonna et al. (2006) also showed specifically that presynaptic terminals opposite DAGL positive spines are CB1-positive, indicating that DAGL is perfectly positioned to promote retrograde transmission, presumably mediated by $2-\mathrm{AG}$ at numerous sites throughout the hippocampus and dentate gyrus.

\section{Physiological role for ECs in the dentate}

Early efforts to examine the neurophysiological effects of cannabinoids began well before isolation and cloning of the $\mathrm{CB} 1$ receptor. Both in vivo and in vitro approaches were employed; experimental measures ranged from auditory and sensory evoked potentials to extracellular field potentials and unit recordings. Using such techniques, a number of studies specifically demonstrated effects of cannabinoids on identified cells or circuits in the dentate gyrus (for example see Kujtan et al., 1983; Campbell et al., 1986a; Campbell et al., 1986b; Wilkison and Pontzer, 1987; Hampson et al., 1989). However, just as cloning of the CB1 receptor and development of powerful immunohistochemical techniques dramatically expanded our understanding of CB1 expression in the brain, major advances in electrophysiological techniques have now provided the technology necessary to dissect the effects of both endogenous and exogenous cannabinoids at the synaptic level. Admittedly, applications of such technology to the study of cannabinoid-dependent systems in the dentate gyrus are only recently beginning to appear in the literature. Nevertheless, the emphasis below will be on such 
recent findings, with a particular effort to note when and where physiological findings to date are consistent with predictions based on the existing anatomical information reviewed above.

\section{DSI in the dentate gyrus}

Anatomical studies reviewed earlier strongly suggest that CB1-positive GABAergic terminals of CCK-positive basket cells make numerous synaptic contacts with both granule cells and hilar mossy cells. These findings suggest such inputs may be modulated by CB1 agonists. Further, the presence of FAAH and/or DAGL in both granule cells and mossy cells suggests they may represent sources of endogenous cannabinoids. Detailed physiological studies have now strongly reinforced these conclusions.

The first evidence that GABAergic inputs to dentate granule cells were sensitive to exogenous cannabinoids was published 2000 when Hájos et al. used whole-cell recording techniques to demonstrate that evoked IPSCs recorded from dentate granule cells were reduced to $36 \pm 6 \%$ of baseline by bath application of WIN55,212-2 in wild type but not in $\mathrm{CB}^{-/-}$mice (Hajos et al., 2000). Several years later, Nakatsuka et al. (2003) similarly reported a WIN55,212-2mediated, AM-251-sensitive reduction in both frequency and amplitude of spontaneous IPSCs (sIPSCs) recorded from dentate granule cells in the human dentate gyrus. These findings indicated that GABAergic inputs to dentate granule cells are indeed inhibited by $\mathrm{CB} 1$ receptor activation, however they did not directly address the question of whether granule cells were capable of activating these receptors by signalling via endogenous cannabinoids.

That question was answered in the affirmative with the first complete characterization of DSI in dentate granule cells in 2005 (Isokawa and Alger, 2005). This study specifically demonstrated that direct depolarization of a single dentate granule cell reduces the amplitude of both sIPSCs and IPSCs evoked by stimulation of the molecular layer (Fig. 2A). Endocannabinoids were implicated in this process because both CP55,942 and WIN55,212-2 mimicked and occluded DSI and because DSI was blocked by the CB1 antagonist SR141716A. These authors further demonstrated that the magnitude of DSI correlated with the extent of depolarization-induced increases in $\left[\mathrm{Ca}^{2+}\right]_{\mathrm{i}}$ and that DSI could be blocked by chelating postsynaptic calcium with internal BAPTA. Finally, this study indicated a particular role for calcium release from ryanodine sensitive internal calcium stores in the mechanism of DSI, as depletion of those stores reduced both $\left[\mathrm{Ca}^{2+}\right]_{\mathrm{i}}$ and the magnitude of DSI.

Interestingly, an earlier study had demonstrated that although DSI of sIPSCs was absent in dentate granule cells in control conditions, it could be detected one week or more following induction of febrile seizures (Chen et al., 2003). Induction of febrile seizures also enhanced EC-mediated signalling in area CA1, apparently due to increases in CB1 expression that were restricted to CCK-positive GABAergic terminals. While the finding that febrile seizures upregulate EC-mediated signalling throughout the hippocampus and dentate gyrus remains quite intriguing, the apparent discrepancy with respect to the ability to detect DSI in dentate granule cells in control conditions remains unexplained.

Also consistent with predictions based on anatomical data is a recent report from my laboratory which provides the first published characterization of DSI as observed in hilar mossy cells (Hofmann et al., 2006). Specifically, we reported DSI of eIPSCs in hilar mossy cells that depends on both postsynaptic calcium influx and presynaptic CB1 receptors. The magnitude of DSI in hilar mossy cells was directly dependent on depolarization duration, and enhanced by bath application of carbachol (CCh). Further, the presynaptic mechanism of inhibition was found to be largely or exclusively selective for calcium-dependent release events (Fig. 2B). We also used dual whole cell recording techniques to demonstrate that there are tight spatial constraints on diffusion of ECs released from hilar mossy cells. Finally, we were intrigued to observe two different forms of expression of DSI of sIPSCs that depended on whether the 
sIPSCs had high spectral power at theta frequencies. Cumulatively, these results suggested a prominent role for EC-mediated signalling between hilar mossy cells and GABAergic afferents in normal hilar function, and raise interesting questions about the effects of both ECs and CCh on coordinated activity in GABAergic networks. An earlier report form another laboratory indicating DSI of sIPSCs could be detected in hilar mossy cells appeared in abstract form (Howard et al., 2003).

\section{Evidence that ECs modulate glutamatergic transmission in the dentate gyrus}

The axon terminals of mossy fibers, perforant path inputs, mossy cells, and back-projecting CA3 pyramidal cells all form glutamatergic synapses within the dentate gyrus. Nevertheless, I think it is fair to say that despite a number of studies clearly indicating antiepileptic (Consroe et al., 1975; Consroe and Wolkin, 1977; Wallace et al., 2001; Wallace et al., 2002; Wallace et al., 2003; Blair et al., 2006), and neuroprotective (Nagayama et al., 1999; Braida et al., 2000; Van der Stelt et al., 2001a; Van der Stelt et al., 2001b; Van der Stelt et al., 2002; Khaspekov et al., 2004) effects of cannabinoids, there is a notable lack of physiological studies that directly test the hypothesis that ECs can modulate excitatory transmission at these synapses. For example, to my knowledge, there are currently no published reports directly testing effects of ECs on mossy fiber transmission. Preliminary data from my lab is consistent with the weight of existing anatomical evidence in suggesting that isolated mossy fiber inputs to $\mathrm{CA} 3$ pyramidal cells are indeed CB1-negative; however it must be noted that neither our preliminary work nor existing anatomical data can at present explicitly rule out the possibility of additional non-CB1 receptors for endocannabinoids at these terminals.

There are somewhat more available data with respect to perforant path inputs to dentate granule cells. Although these inputs were initially reported to be insensitive to $\Delta^{9}$-THC using in vivo extracellular recording techniques (Wilkison and Pontzer, 1987), two later reports using different agonists and activation strategies have been consistent with the hypothesis that these terminals may express presynaptic CB1 receptors. One such study explicitly demonstrated that bath application of WIN55,212-2 produced a rightward shift in the input/output curve, and a reduction in paired pulse facilitation, of perforant path synaptic potentials recorded from the outer third of the molecular layer (Kirby et al., 1995). Further, another study examining field potential responses produced by stimulation of the medial perforant path strikingly found that reductions in fEPSPs produced by an acetylcholinesterase inhibitor (physostigmine) were blocked by the CB1 receptor antagonist AM-251, but not by methoctramine, an antagonist presumably selective for presynaptic (m2) muscarinic acetylcholine receptors. These results suggested that cholinergic facilitation of EC release can lead to tonic EC-mediated inhibition of perforant path inputs to dentate granule cells, and as such may be consistent with anatomical studies which indicate low levels of CB1 expression in the outer two thirds of the molecular layer.

There is also very limited available data that directly addresses whether ECs play a role in modulating release of glutamate from mossy cell axon terminals. Likely sensitivity to inhibition by CB1 activation has been suggested, of course, by recent and striking immunohistochemical findings reviewed earlier, but it is also implicated by the demonstration that WIN55,212-2 sensitive eIPSCs can be produced in dentate granule cells by stimulation in the inner molecular layer, and perhaps most notably by the observation that CB1 receptor knockouts that are selective for glutamatergic neurons reduce the threshold for kainic acid-induced seizures (Marsicano et al., 2003; Monory et al., 2006). Nevertheless, it is likely that much remains to be learned from a detailed electrophysiological examination of EC-mediated signalling at this synapse. Finally, there is also a complete lack of information in the literature about the EC sensitivity of back projecting associational/commissural inputs to hilar neurons or dentate granule cells. As the functional consequences of CB1 receptor activation on Schaffer Collateral 
inputs to CA1 pyramidal cells is currently a matter of much debate and investigation (see Introduction) it will not be reviewed further here.

\section{A role for endocannabinoids in neurogenesis?}

In contrast to original conclusions, groundbreaking work over the last 10-15 years has clearly demonstrated that neurogenesis does occur in selective regions of the adult mammalian CNS, most notably in the olfactory bulb and dentate gyrus (for recent review see Lledo et al., 2006). Indeed, the subgranular zone of the dentate gyrus, previously recognized for intense expression of CB1 receptors in a subset of inhibitory interneurons, has now also been recognized as a primary neuroproliferative zone. Further, Jiang et al. (2005) has used immunohistochemical techniques coupled with injections of 5-bromo-2-deoxyuridine (BrdU, a base analog of thymidine) to show that dividing cells in the subgranular region of the adult rat dentate gyrus are immunoreactive for CB1. These striking findings, coupled with work completed in culture, have clearly suggested the hypothesis that EC-mediated signalling might modulate neurogenesis in vivo. Consistent with that hypothesis, Jiang et al. (2005) also demonstrated that chronic administration of a synthetic cannabinoid (HU210) increased neurogenesis in the adult dentate gyrus, coincident with anxiolytic and antidepressant like effects. At present, two other studies have made a compatible observation that BrdU-labeling of newborn cells in the adult dentate gyrus is dramatically reduced in CB1 knockout animals compared to wild type mice (Jin et al., 2004; Kim et al., 2006). However, the full story here is likely to be quite complicated because apparently paradoxical increases in neurogenesis produced by administration of CB1 antagonists, including SR141716A and AM-251, prior to BrdU-labeling have been noted by several labs (Rueda et al., 2002; Jin et al., 2004). Further, in at least one case, an AEA-mediated reduction in neurogenesis in the dentate gyrus has been reported (Rueda et al., 2002). One possible explanation is that apparent inhibitory effects of cannabinoids on neurogenesis, when they occur, may be CB1 receptor-independent, and perhaps mediated by direct activation of VR1. This is consistent with the observation by Jin et al. (2004) that SR141716A-mediated increases in neurogenesis were preserved in CB1 knockouts, but absent in VR1 knockouts, and also compatible with a much earlier report indicating that both AEA and SR141716A may interact with VR1 receptors (Zygmunt et al., 1999). In contrast, the most recent mechanism suggested for CB1-dependent increases in neurogenesis implicate down regulation of nitric oxide synthase (Di Marzo et al., 2002; Kim et al., 2006).

\section{Non-CB receptor targets of ECs relevant to the dentate}

A final topic worthy of particular consideration here is the possible abundance of non-CB1 targets for EC-mediated signalling in the dentate gyrus. Although 2-AG has been postulated to be the retrograde messenger in many forms of EC-mediated signalling, a role for AEA is far from ruled out. In fact, a role for AEA is implied by the presence of FAAH in hippocampal principal cells and dentate granule cells, and has occasionally been implicated in depolarization-induced as opposed to synaptically-driven release of ECs (for review see Chevaleyre et al., 2006). The extent to which EC-mediated signalling involves AEA is a particularly important question in large part because AEA and its metabolites, far more than 2-AG, have been associated with action at non-CB receptor sites (for review see Di Marzo et al., 2002).

One such site that may have an important role to play in the dentate gyrus is the VR1 receptor. Of course, VR1 receptor expression is typically associated with sensory fibers, and thus much of the data implicating an interaction of AEA and VR1 is based on apparent AEA-mediated increases in VR1-dependent release of calcitonin gene-related peptide (CGRP). However, AEA and its analogues have also been shown to directly activate recombinant VR1 receptors in several types of assays and expression systems (Ralevic et al., 2001; Bisogno et al., 2001; 
Di Marzo et al., 2001). Further, recent immunohistochemical data has indicated a prominent expression of VR1 in the brain, with particularly high levels in several areas, including the dentate gyrus (Toth et al., 2005). Collectively these findings suggest an interaction between AEA and VR1 may be relevant to understanding EC-mediated signalling in the dentate. This argument is further supported, albeit indirectly, by reports in other areas of the CNS where VR1 activation by AEA and/or capsaicin has been shown to directly modulate synaptic transmission (Marinelli et al., 2002; Marinelli et al., 2003). Other potential targets for AEA that could be significant in the dentate include $\alpha 7$-containing nicotinic acetylcholine receptors and $5-\mathrm{HT}_{3}$ receptors. Interestingly, in both these cases, action of AEA has been shown to have inhibitory effects on recombinant receptors expressed in Xenopus oocytes (Oz et al., 2002; Oz et al., 2003), while additional lines of evidence implicating cannabinoids in serotonergic function have been previously reviewed (Morales, 2006). Further, a potential non-competitive interaction between AEA and muscarinic acetylcholine receptors has been suggested in both binding and functional assays (Christopoulos and Wilson, 2001; Lanzafame et al., 2004).

\section{Conclusions and Future Directions}

The data reviewed here indicate the presence of a robust system for EC-mediated signalling in the dentate gyrus that is clearly composed of both synthetic and degradative enzymes for endocannabinoids as well as cannabinoid receptors. A significant body of work reviewed here has largely coalesced to indicate that there is prominent expression of $\mathrm{CB} 1$ receptors on the axon terminals of CCK-positive basket cells in the dentate, and that these CB1-positive terminals likely form numerous synaptic contacts with both granule cells and hilar mossy cells. Consistent with that view, recent work has demonstrated robust modulation of GABAergic synapses to both granule cells and mossy cells that does indeed depend on retrograde activation of CB1 receptors by endogenous cannabinoids (Isokawa and Alger, 2005; Hofmann et al., 2006). Until very recently, available data suggested that we would be unlikely to observe major effects of ECs at other types of synapses in the dentate. However, dramatic improvements in immunohistochemical techniques have now clearly challenged that conclusion by indicating robust expression of CB1 receptors on excitatory terminals in the inner third of the molecular layer that are likely to arise from hilar mossy cells, and that appear to be key players in determining threshold to kainic acid-induced seizures (Marsicano et al., 2003; Katona et al., 2006; Monory et al., 2006). These striking findings have strongly reinforced the notion of the dentate gyrus as a key player in EC-mediated signalling, and may highlight it as an attractive system for future research on EC-mediated modulation of glutamatergic transmission.

That being said, it seems clear that we still have much to learn from a continued characterization of the EC system at the electron microscopic level, particularly when coupled with detailed physiological studies at the synaptic level. In fact, a number of issues beyond transmitter phenotype are likely to be of particular importance. These include developing a better understanding of physiological stimuli that trigger EC-mediated signalling and more accurate measures of the scope of the effects. This will likely involve further examination of the role of postsynaptic metabotropic receptors in the release process and careful evaluation of potential heterosynaptic and metaplastic signalling mechanisms. At a larger level, it will also be important to understand broader effects of ECs on network activity, where both in vitro and in vivo studies focused on the dentate gyrus will likely be central to elucidating the neuroprotective and antiepileptic effects of cannabinoids. Finally, the potential role of ECs in neurogenesis is an extremely important topic that clearly has broad implications for neurobiology. Although the dentate gyrus has arguably been partially overlooked in the rapid pace of the last five years, it now seems clear that those motivated to understand EC-mediated signalling in the CNS have cause to look towards the dentate, while conversely, those who seek a more thorough understanding of the dentate may find significant value in further studies of cannabinoids. 


\section{Reference List}

Acsady L, Katona I, Martinez-Guijarro FJ, Buzsaki G, Freund TF. Unusual Target Selectivity of Perisomatic Inhibitory Cells in the Hilar Region of the Rat Hippocampus. J Neurosci 2000;20:69076919. [PubMed: 10995835]

Alger BE. Retrograde signaling in the regulation of synaptic transmission: focus on endocannabinoids. Prog Neurobiol 2002;68:247-286. [PubMed: 12498988]

Beltramo M, Stella N, Calignano A, Lin SY, Makriyannis A, Piomelli D. Functional role of high-affinity anandamide transport, as revealed by selective inhibition. Science 1997;277:1094-1097. [PubMed: 9262477]

Berdyshev EV. Cannabinoid receptors and the regulation of immune response. Chem Phys Lipids 2000;108:169-190. [PubMed: 11106790]

Bisogno T, Hanus L, De PL, Tchilibon S, Ponde DE, Brandi I, Moriello AS, Davis JB, Mechoulam R, Di Marzo V. Molecular targets for cannabidiol and its synthetic analogues: effect on vanilloid VR1 receptors and on the cellular uptake and enzymatic hydrolysis of anandamide. Br J Pharmacol 2001;134:845-852. [PubMed: 11606325]

Blair RE, Deshpande LS, Sombati S, Falenski KW, Martin BR, Delorenzo RJ. Activation of the cannabinoid type-1 receptor mediates the anticonvulsant properties of cannabinoids in the hippocampal neuronal culture models of acquired epilepsy and status epilepticus. J Pharmacol Exp Ther 2006;317:1072-1078. [PubMed: 16469864]

Bodor AL, Katona I, Nyiri G, Mackie K, Ledent C, Hajos N, Freund TF. Endocannabinoid signaling in rat somatosensory cortex: laminar differences and involvement of specific interneuron types. J Neurosci 2005;25:6845-6856. [PubMed: 16033894]

Braida D, Pozzi M, Sala M. CP 55,940 protects against ischemia-induced electroencephalographic flattening and hyperlocomotion in Mongolian gerbils. Neurosci Lett 2000;296:69-72. [PubMed: 11108983]

Cadas H, di TE, Piomelli D. Occurrence and biosynthesis of endogenous cannabinoid precursor, Narachidonoyl phosphatidylethanolamine, in rat brain. J Neurosci 1997;17:1226-1242. [PubMed: 9006968]

Cadas H, Gaillet S, Beltramo M, Venance L, Piomelli D. Biosynthesis of an endogenous cannabinoid precursor in neurons and its control by calcium and cAMP. J Neurosci 1996;16:3934-3942. [PubMed: 8656287]

Campbell KA, Foster TC, Hampson RE, Deadwyler SA. delta 9-Tetrahydrocannabinol differentially affects sensory-evoked potentials in the rat dentate gyrus. J Pharmacol Exp Ther 1986a;239:936940. [PubMed: 3025423]

Campbell KA, Foster TC, Hampson RE, Deadwyler SA. Effects of delta 9-tetrahydrocannabinol on sensory-evoked discharges of granule cells in the dentate gyrus of behaving rats. J Pharmacol Exp Ther 1986b;239:941-945. [PubMed: 3025424]

Chen K, Ratzliff A, Hilgenberg L, Gulyas A, Freund TF, Smith M, Dinh TP, Piomelli D, Mackie K, Soltesz I. Long-term plasticity of endocannabinoid signaling induced by developmental febrile seizures. Neuron 2003;39:599-611. [PubMed: 12925275]

Chevaleyre V, Castillo PE. Heterosynaptic LTD of hippocampal GABAergic synapses: a novel role of endocannabinoids in regulating excitability. Neuron 2003;38:461-472. [PubMed: 12741992]

Chevaleyre V, Castillo PE. Endocannabinoid-mediated metaplasticity in the hippocampus. Neuron 2004;43:871-881. [PubMed: 15363397]

Chevaleyre V, Takahashi KA, Castillo PE. Endocannabinoid-Mediated Synaptic Plasticity in the CNS. Annu Rev Neurosci. 2006

Christopoulos A, Wilson K. Interaction of anandamide with the M(1) and M(4) muscarinic acetylcholine receptors. Brain Res 2001;915:70-78. [PubMed: 11578621]

Consroe P, Wolkin A. Cannabidiol--antiepileptic drug comparisons and interactions in experimentally induced seizures in rats. J Pharmacol Exp Ther 1977;201:26-32. [PubMed: 850145]

Consroe PF, Wood GC, Buchsbaum H. Anticonvulsant nature of marihuana smoking. JAMA 1975;234:306-307. [PubMed: 808653] 
Cravatt BF, Giang DK, Mayfield SP, Boger DL, Lerner RA, Gilula NB. Molecular characterization of an enzyme that degrades neuromodulatory fatty-acid amides. Nature 1996;384:83-87. [PubMed: 8900284]

Cristino L, De PL, Pryce G, Baker D, Guglielmotti V, Di Marzo V. Immunohistochemical localization of cannabinoid type 1 and vanilloid transient receptor potential vanilloid type 1 receptors in the mouse brain. Neuroscience 2006;139:1405-1415. [PubMed: 16603318]

De PL, Melck D, Bisogno T, Di Marzo V. Endocannabinoids and fatty acid amides in cancer, inflammation and related disorders. Chem Phys Lipids 2000;108:191-209. [PubMed: 11106791]

Deutsch DG, Ueda N, Yamamoto S. The fatty acid amide hydrolase (FAAH). Prostaglandins Leukot Essent Fatty Acids 2002;66:201-210. [PubMed: 12052036]

Devane WA, Hanus L, Breuer A, Pertwee RG, Stevenson LA, Griffin G, Gibson D, Mandelbaum A, Etinger A, Mechoulam R. Isolation and structure of a brain constituent that binds to the cannabinoid receptor. Science 1992;258:1946-1949. [PubMed: 1470919]

Di Marzo V, Bisogno T, De PL, Brandi I, Jefferson RG, Winckler RL, Davis JB, Dasse O, Mahadevan A, Razdan RK, Martin BR. Highly selective CB(1) cannabinoid receptor ligands and novel CB(1)/ VR(1) vanilloid receptor "hybrid" ligands. Biochem Biophys Res Commun 2001;281:444-451. [PubMed: 11181068]

Di Marzo V, Bisogno T, De PL, Melck D, Martin BR. Cannabimimetic fatty acid derivatives: the anandamide family and other endocannabinoids. Curr Med Chem 1999;6:721-744. [PubMed: 10469888]

Di Marzo V, De PL, Fezza F, Ligresti A, Bisogno T. Anandamide receptors. Prostaglandins Leukot Essent Fatty Acids 2002;66:377-391. [PubMed: 12052051]

Di Marzo V, Deutsch DG. Biochemistry of the endogenous ligands of cannabinoid receptors. Neurobiol Dis 1998;5:386-404. [PubMed: 9974173]

Di Marzo V, Fontana A, Cadas H, Schinelli S, Cimino G, Schwartz JC, Piomelli D. Formation and inactivation of endogenous cannabinoid anandamide in central neurons. Nature 1994;372:686-691. [PubMed: 7990962]

Di S, Boudaba C, Popescu IR, Weng FJ, Harris C, Marcheselli VL, Bazan NG, Tasker JG. Activitydependent release and actions of endocannabinoids in the rat hypothalamic supraoptic nucleus. $\mathrm{J}$ Physiol 2005;569:751-760. [PubMed: 16239276]

Dinh TP, Carpenter D, Leslie FM, Freund TF, Katona I, Sensi SL, Kathuria S, Piomelli D. Brain monoglyceride lipase participating in endocannabinoid inactivation. Proc Natl Acad Sci U S A 2002;99:10819-10824. [PubMed: 12136125]

Domenici MR, Azad SC, Marsicano G, Schierloh A, Wotjak CT, Dodt HU, Zieglgansberger W, Lutz B, Rammes G. Cannabinoid Receptor Type 1 Located on Presynaptic Terminals of Principal Neurons in the Forebrain Controls Glutamatergic Synaptic Transmission. J Neurosci 2006;26:5794-5799. [PubMed: 16723537]

Egertova M, Cravatt BF, Elphick MR. Comparative analysis of fatty acid amide hydrolase and cb(1) cannabinoid receptor expression in the mouse brain: evidence of a widespread role for fatty acid amide hydrolase in regulation of endocannabinoid signaling. Neuroscience 2003;119:481-496. [PubMed: 12770562]

Egertova M, Elphick MR. Localisation of cannabinoid receptors in the rat brain using antibodies to the intracellular C-terminal tail of CB. J Comp Neurol 2000;422:159-171. [PubMed: 10842224]

Egertova M, Giang DK, Cravatt BF, Elphick MR. A new perspective on cannabinoid signalling: complementary localization of fatty acid amide hydrolase and the $\mathrm{CB} 1$ receptor in rat brain. Proc Biol Sci 1998;265:2081-2085. [PubMed: 9842734]

Engler B, Freiman I, Urbanski M, Szabo B. Effects of Exogenous and Endogenous Cannabinoids on GABAergic Neurotransmission between the Caudate-Putamen and the Globus Pallidus in the Mouse. J Pharmacol Exp Ther 2006;316:608-617. [PubMed: 16214880]

Freund TF, Katona I, Piomelli D. Role of endogenous cannabinoids in synaptic signaling. Physiol Rev 2003;83:1017-1066. [PubMed: 12843414]

Fukudome Y, Ohno-Shosaku T, Matsui M, Omori Y, Fukaya M, Tsubokawa H, Taketo MM, Watanabe M, Manabe T, Kano M. Two distinct classes of muscarinic action on hippocampal inhibitory 
synapses: M2-mediated direct suppression and M1/M3-mediated indirect suppression through endocannabinoid signalling. Eur J Neurosci 2004;19:2682-2692. [PubMed: 15147302]

Gaoni Y, Mechoulam R. Isolation, structure and partial synthesis of an active constituent of hashish. J Am Chem Soc 1964;86:1646-1647.

Glass M, Dragunow M, Faull RL. Cannabinoid receptors in the human brain: a detailed anatomical and quantitative autoradiographic study in the fetal, neonatal and adult human brain. Neuroscience 1997;77:299-318. [PubMed: 9472392]

Gulyas AI, Cravatt BF, Bracey MH, Dinh TP, Piomelli D, Boscia F, Freund TF. Segregation of two endocannabinoid-hydrolyzing enzymes into pre- and postsynaptic compartments in the rat hippocampus, cerebellum and amygdala. Eur J Neurosci 2004;20:441-458. [PubMed: 15233753]

Hajos N, Freund TF. Pharmacological separation of cannabinoid sensitive receptors on hippocampal excitatory and inhibitory fibers. Neuropharm 2002;43:503-510.

Hajos N, Katona I, Naiem SS, Mackie K, Ledent C, Mody I, Freund TF. Cannabinoids inhibit hippocampal GABAergic transmission and network oscillations. Eur J Neurosci 2000;12:3239_ 3249. [PubMed: 10998107]

Hampson RE, Foster TC, Deadwyler SA. Effects of delta-9-tetrahydrocannabinol on sensory evoked hippocampal activity in the rat: principal components analysis and sequential dependency. $\mathrm{J}$ Pharmacol Exp Ther 1989;251:870-877. [PubMed: 2557421]

Harkany T, Dobszay MB, Cayetanot F, Hartig W, Siegemund T, Aujard F, Mackie K. Redistribution of CB1 cannabinoid receptors during evolution of cholinergic basal forebrain territories and their cortical projection areas: a comparison between the gray mouse lemur (Microcebus murinus, primates) and rat. Neuroscience 2005;135:595-609. [PubMed: 16129564]

Harris LS, Carchman RA, Martin BR. Evidence for the existence of specific cannabinoid binding sites. Life Sci 1978;22:1131-1137. [PubMed: 661500]

Hashimotodani Y, Ohno-Shosaku T, Tsubokawa H, Ogata H, Emoto K, Maejima T, Araishi K, Shin HS, Kano M. Phospholipase Cbeta serves as a coincidence detector through its $\mathrm{Ca} 2+$ dependency for triggering retrograde endocannabinoid signal. Neuron 2005;45:257-268. [PubMed: 15664177]

Herkenham M, Lynn AB, de Costa BR, Richfield EK. Neuronal localization of cannabinoid receptors in the basal ganglia of the rat. Brain Res 1991a;547:267-274. [PubMed: 1909204]

Herkenham M, Lynn AB, Johnson MR, Melvin LS, de Costa BR, Rice KC. Characterization and localization of cannabinoid receptors in rat brain: a quantitative in vitro autoradiographic study. $\mathrm{J}$ Neurosci 1991b;11:563-583. [PubMed: 1992016]

Herkenham M, Lynn AB, Johnson MR, Melvin LS, de Costa BR, Rice KC. Characterization and localization of cannabinoid receptors in rat brain: a quantitative in vitro autoradiographic study. $\mathrm{J}$ Neurosci 1991c;11:563-583. [PubMed: 1992016]

Hermann H, Marsicano G, Lutz B. Coexpression of the cannabinoid receptor type 1 with dopamine and serotonin receptors in distinct neuronal subpopulations of the adult mouse forebrain. Neuroscience 2002;109:451-460. [PubMed: 11823058]

Hillard CJ, Edgemond WS, Jarrahian A, Campbell WB. Accumulation of N-arachidonoylethanolamine (anandamide) into cerebellar granule cells occurs via facilitated diffusion. J Neurochem 1997;69:631-638. [PubMed: 9231721]

Hillard CJ, Wilkison DM, Edgemond WS, Campbell WB. Characterization of the kinetics and distribution of $\mathrm{N}$-arachidonylethanolamine (anandamide) hydrolysis by rat brain. Biochim Biophys Acta 1995;1257:249-256. [PubMed: 7647100]

Hoffman AF, Macgill AM, Smith D, Oz M, Lupica CR. Species and strain differences in the expression of a novel glutamate-modulating cannabinoid receptor in the rodent hippocampus. Eur J Neurosci 2005;22:2387-2391. [PubMed: 16262678]

Hoffman AF, Oz M, Caulder T, Lupica CR. Functional tolerance and blockade of long-term depression at synapses in the nucleus accumbens after chronic cannabinoid exposure. J Neurosci 2003;23:48154820. [PubMed: 12832502]

Hofmann ME, Nahir B, Frazier CJ. Endocannabinoid mediated depolarization-induced suppression of inhibition in hilar mossy cells of the rat dentate gyrus. J Neurophysiol 2006;96:2501-2512. [PubMed: 16807350] 
Howlett AC, Bidaut-Russell M, Devane WA, Melvin LS, Johnson MR, Herkenham M. The cannabinoid receptor: biochemical, anatomical and behavioral characterization. Trends Neurosci 1990;13:420423. [PubMed: 1700516]

Isokawa M, Alger BE. Retrograde endocannabinoid regulation of GABAergic inhibition in the rat dentate gyrus granule cell. J Physiol 2005;567:1001-1010. [PubMed: 16037085]

Jiang W, Zhang Y, Xiao L, Van CJ, Ji SP, Bai G, Zhang X. Cannabinoids promote embryonic and adult hippocampus neurogenesis and produce anxiolytic- and antidepressant-like effects. J Clin Invest 2005;115:3104-3116. [PubMed: 16224541]

Jin K, Xie L, Kim SH, Parmentier-Batteur S, Sun Y, Mao XO, Childs J, Greenberg DA. Defective adult neurogenesis in CB1 cannabinoid receptor knockout mice. Mol Pharmacol 2004;66:204-208. [PubMed: 15266010]

Katona I, Sperlagh B, Magloczky Z, Santha E, Kofalvi A, Czirjak S, Mackie K, Vizi ES, Freund TF. GABAergic interneurons are the targets of cannabinoid actions in the human hippocampus. Neuroscience 2000;100:797-804. [PubMed: 11036213]

Katona I, Sperlagh B, Sik A, Kafalvi A, Vizi ES, Mackie K, Freund TF. Presynaptically located CB1 cannabinoid receptors regulate GABA release from axon terminals of specific hippocampal interneurons. J Neurosci 1999;19:4544-4558. [PubMed: 10341254]

Katona I, Urban GM, Wallace M, Ledent C, Jung KM, Piomelli D, Mackie K, Freund TF. Molecular Composition of the Endocannabinoid System at Glutamatergic Synapses. J Neurosci 2006;26:56285637. [PubMed: 16723519]

Khaspekov LG, Brenz Verca MS, Frumkina LE, Hermann H, Marsicano G, Lutz B. Involvement of brainderived neurotrophic factor in cannabinoid receptor-dependent protection against excitotoxicity. Eur J Neurosci 2004;19:1691-1698. [PubMed: 15078543]

Kim SH, Won SJ, Mao XO, Ledent C, Jin K, Greenberg DA. Role for Neuronal Nitric Oxide Synthase in Cannabinoid-induced Neurogenesis. J Pharmacol Exp Ther. 2006

Kirby MT, Hampson RE, Deadwyler SA. Cannabinoids selectively decrease paired-pulse facilitation of perforant path synaptic potentials in the dentate gyrus in vitro. Brain Res 1995;688:114-120. [PubMed: 8542297]

Kreitzer AC, Regehr WG. Cerebellar depolarization-induced suppression of inhibition is mediated by endogenous cannabinoids. J Neurosci 2001a;21:RC174. [PubMed: 11588204]

Kreitzer AC, Regehr WG. Retrograde inhibition of presynaptic calcium influx by endogenous cannabinoids at excitatory synapses onto Purkinje cells. Neuron 2001b;29:717-727. [PubMed: 11301030]

Kujtan PW, Carlen PL, Kapur BM. delta 9-Tetrahydrocannabinol and cannabidiol: dose-dependent effects on evoked potentials in the hippocampal slice. Can J Physiol Pharmacol 1983;61:420-426. [PubMed: 6305469]

Lanzafame AA, Guida E, Christopoulos A. Effects of anandamide on the binding and signaling properties of M1 muscarinic acetylcholine receptors. Biochem Pharmacol 2004;68:2207-2219. [PubMed: 15498511]

Llano I, Leresche N, Marty A. Calcium entry increases the sensitivity of cerebellar Purkinje cells to applied GABA and decreases inhibitory synaptic currents. Neuron 1991;6:565-574. [PubMed: 2015092]

Lledo PM, Alonso M, Grubb MS. Adult neurogenesis and functional plasticity in neuronal circuits. Nat Rev Neurosci 2006;7:179-193. [PubMed: 16495940]

Lutz B. Molecular biology of cannabinoid receptors. Prostaglandins Leukot Essent Fatty Acids 2002;66:123-142. [PubMed: 12052031]

Maejima T, Hashimoto K, Yoshida T, Aiba A, Kano M. Presynaptic inhibition caused by retrograde signal from metabotropic glutamate to cannabinoid receptors. Neuron 2001;31:463-475. [PubMed: 11516402]

Maejima T, Oka S, Hashimotodani Y, Ohno-Shosaku T, Aiba A, Wu D, Waku K, Sugiura T, Kano M. Synaptically Driven Endocannabinoid Release Requires Ca2+-Assisted Metabotropic Glutamate Receptor Subtype 1 to Phospholipase C \{beta\}4 Signaling Cascade in the Cerebellum. J Neurosci 2005;25:6826-6835. [PubMed: 16033892] 
Mailleux P, Parmentier M, Vanderhaeghen JJ. Distribution of cannabinoid receptor messenger RNA in the human brain: an in situ hybridization histochemistry with oligonucleotides. Neurosci Lett 1992;143:200-204. [PubMed: 1436667]

Mailleux P, Vanderhaeghen JJ. Distribution of neuronal cannabinoid receptor in the adult rat brain: a comparative receptor binding radioautography and in situ hybridization histochemistry. Neuroscience 1992;48:655-668. [PubMed: 1376455]

Marinelli S, Di Marzo V, Berretta N, Matias I, Maccarrone M, Bernardi G, Mercuri NB. Presynaptic facilitation of glutamatergic synapses to dopaminergic neurons of the rat substantia nigra by endogenous stimulation of vanilloid receptors. J Neurosci 2003;23:3136-3144. [PubMed: 12716921]

Marinelli S, Vaughan CW, Christie MJ, Connor M. Capsaicin activation of glutamatergic synaptic transmission in the rat locus coeruleus in vitro. J Physiol 2002;543:531-540. [PubMed: 12205187]

Marsicano G, Goodenough S, Monory K, Hermann H, Eder M, Cannich A, Azad SC, Cascio MG, Gutierrez SO, Van der Stelt M, Lopez-Rodriguez ML, Casanova E, Schutz G, Zieglgansberger W, Di Marzo V, Behl C, Lutz B. CB1 cannabinoid receptors and on-demand defense against excitotoxicity. Science 2003;302:84-88. [PubMed: 14526074]

Marsicano G, Lutz B. Expression of the cannabinoid receptor CB1 in distinct neuronal subpopulations in the adult mouse forebrain. Eur J Neurosci 1999;11:4213-4225. [PubMed: 10594647]

Marsicano G, Lutz B. Neuromodulatory functions of the endocannabinoid system. J Endocrinol Invest 2006;29:27-46. [PubMed: 16751707]

Marsicano G, Wotjak CT, Azad SC, Bisogno T, Rammes G, Cascio MG, Hermann H, Tang J, Hofmann C, Zieglgansberger W, Di Marzo V, Lutz B. The endogenous cannabinoid system controls extinction of aversive memories. Nature 2002;418:530-534. [PubMed: 12152079]

Matsuda LA, Bonner TI, Lolait SJ. Localization of cannabinoid receptor mRNA in rat brain. J Comp Neurol 1993;327:535-550. [PubMed: 8440779]

Matsuda LA, Lolait SJ, Brownstein MJ, Young AC, Bonner TI. Structure of a cannabinoid receptor and functional expression of the cloned cDNA. Nature 1990;346:561-564. [PubMed: 2165569]

Melis M, Pistis M, Perra S, Muntoni AL, Pillolla G, Gessa GL. Endocannabinoids mediate presynaptic inhibition of glutamatergic transmission in rat ventral tegmental area dopamine neurons through activation of CB1 receptors. J Neurosci 2004a;24:53-62. [PubMed: 14715937]

Melis M, Perra S, Muntoni AL, Pillolla G, Lutz B, Marsicano G, Di Marzo V, Gessa GL, Pistis M. Prefrontal Cortex Stimulation Induces 2-Arachidonoyl-Glycerol-Mediated Suppression of Excitation in Dopamine Neurons. J Neurosci 2004b;24:10707-10715. [PubMed: 15564588]

Monory K, Massa F, Egertova M, Eder M, Blaudzun H, Westenbroek R, Kelsch W, Jacob W, Marsch R, Ekker M, Long J, Rubenstein JL, Goebbels S, Nave KA, During M, Klugmann M, Wolfel B, Dodt HU, Zieglgansberger W, Wotjak CT, Mackie K, Elphick MR, Marsicano G, Lutz B. The endocannabinoid system controls key epileptogenic circuits in the hippocampus. Neuron 2006;51:455-466. [PubMed: 16908411]

Morales, M. Cannabinoids and the Central Serotonergic System. In: Onaivi, ES.; Sugiura, T.; Di Marzo, V., editors. Endocannabinoids. CRC Press; Boca Raton, FL: 2006. p. 249-260.

Morales M, Backman C. Coexistence of serotonin 3 (5-HT3) and CB1 cannabinoid receptors in interneurons of hippocampus and dentate gyrus. Hippocampus 2002;12:756-764. [PubMed: 12542227]

Mukhtarov M, Ragozzino D, Bregestovski P. Dual Ca2+ modulation of glycinergic synaptic currents in rodent hypoglossal motoneurones. J Physiol 2005;569:817-831. [PubMed: 16123105]

Munro S, Thomas KL, bu-Shaar M. Molecular characterization of a peripheral receptor for cannabinoids. Nature 1993;365:61-65. [PubMed: 7689702]

Nagayama T, Sinor AD, Simon RP, Chen J, Graham SH, Jin K, Greenberg DA. Cannabinoids and neuroprotection in global and focal cerebral ischemia and in neuronal cultures. J Neurosci 1999;19:2987-2995. [PubMed: 10191316]

Nakatsuka T, Chen HX, Roper SN, Gu JG. Cannabinoid receptor-1 activation suppresses inhibitory synaptic activity in human dentate gyrus. Neuropharm 2003;45:116-121.

Ohno-Shosaku T, Hashimotodani Y, Maejima T, Kano M. Calcium signaling and synaptic modulation: Regulation of endocannabinoid-mediated synaptic modulation by calcium. Cell Calcium. 2005 
Ohno-Shosaku T, Maejima T, Kano M. Endogenous cannabinoids mediate retrograde signals from depolarized postsynaptic neurons to presynaptic terminals. Neuron 2001;29:729-738. [PubMed: 11301031]

Ohno-Shosaku T, Shosaku J, Tsubokawa H, Kano M. Cooperative endocannabinoid production by neuronal depolarization and group I metabotropic glutamate receptor activation. Eur J Neurosci 2002a;15:953-961. [PubMed: 11918654]

Ohno-Shosaku T, Tsubokawa H, Mizushima I, Yoneda N, Zimmer A, Kano M. Presynaptic cannabinoid sensitivity is a major determinant of depolarization-induced retrograde suppression at hippocampal synapses. J Neurosci 2002b;22:3864-3872. [PubMed: 12019305]

Ong WY, Mackie K. A light and electron microscopic study of the CB1 cannabinoid receptor in primate brain. Neuroscience 1999;92:1177-1191. [PubMed: 10426477]

Oz M, Ravindran A, az-Ruiz O, Zhang L, Morales M. The endogenous cannabinoid anandamide inhibits alpha7 nicotinic acetylcholine receptor-mediated responses in Xenopus oocytes. J Pharmacol Exp Ther 2003;306:1003-1010. [PubMed: 12766252]

Oz M, Zhang L, Morales M. Endogenous cannabinoid, anandamide, acts as a noncompetitive inhibitor on 5-HT3 receptor-mediated responses in Xenopus oocytes. Synapse 2002;46:150-156. [PubMed: 12325042]

Pettit DA, Harrison MP, Olson JM, Spencer RF, Cabral GA. Immunohistochemical localization of the neural cannabinoid receptor in rat brain. J Neurosci Res 1998;51:391-402. [PubMed: 9486774]

Piomelli D. The molecular logic of endocannabinoid signalling. Nat Rev Neurosci 2003;4:873-884. [PubMed: 14595399]

Piomelli D, Beltramo M, Glasnapp S, Lin SY, Goutopoulos A, Xie XQ, Makriyannis A. Structural determinants for recognition and translocation by the anandamide transporter. Proc Natl Acad Sci U S A 1999;96:5802-5807. [PubMed: 10318965]

Pitler TA, Alger BE. Postsynaptic spike firing reduces synaptic GABAA responses in hippocampal pyramidal cells. J Neurosci 1992;12:4122-4132. [PubMed: 1403103]

Ralevic V, Kendall DA, Jerman JC, Middlemiss DN, Smart D. Cannabinoid activation of recombinant and endogenous vanilloid receptors. Eur J Pharmacol 2001;424:211-219. [PubMed: 11672565]

Robbe D, Kopf M, Remaury A, Bockaert J, Manzoni OJ. Endogenous cannabinoids mediate long-term synaptic depression in the nucleus accumbens. Proc Natl Acad Sci U S A 2002;99:8384-8388. [PubMed: 12060781]

Romero J, Hillard CJ, Calero M, Rabano A. Fatty acid amide hydrolase localization in the human central nervous system: an immunohistochemical study. Brain Res Mol Brain Res 2002;100:85-93. [PubMed: 12008024]

Roth SH, Williams PJ. The non-specific membrane binding properties of delta9-tetrahydrocannabinol and the effects of various solubilizers. J Pharm Pharmacol 1979;31:224-230. [PubMed: 36461]

Rueda D, Navarro B, Martinez-Serrano A, Guzman M, Galve-Roperh I. The endocannabinoid anandamide inhibits neuronal progenitor cell differentiation through attenuation of the Rap1/B-Raf/ ERK pathway. J Biol Chem 2002;277:46645-46650. [PubMed: 12237305]

Safo PK, Regehr WG. Endocannabinoids control the induction of cerebellar LTD. Neuron 2005;48:647659. [PubMed: 16301180]

Schlicker E, Kathmann M. Modulation of transmitter release via presynaptic cannabinoid receptors. Trends Pharmacol Sci 2001;22:565-572. [PubMed: 11698100]

Skaper SD, Buriani A, Dal TR, Petrelli L, Romanello S, Facci L, Leon A. The ALIAmide palmitoylethanolamide and cannabinoids, but not anandamide, are protective in a delayed postglutamate paradigm of excitotoxic death in cerebellar granule neurons. Proc Natl Acad Sci U S A 1996;93:3984-3989. [PubMed: 8633002]

Stella N, Schweitzer P, Piomelli D. A second endogenous cannabinoid that modulates long-term potentiation. Nature 1997;388:773-778. [PubMed: 9285589]

Sugiura T, Kondo S, Sukagawa A, Nakane S, Shinoda A, Itoh K, Yamashita A, Waku K. 2Arachidonoylglycerol: a possible endogenous cannabinoid receptor ligand in brain. Biochem Biophys Res Commun 1995;215:89-97. [PubMed: 7575630] 
Sugiura, T.; Oka, S.; Ikeda, S.; Waku, K. Occurrence, Biosynthesis, and Metabolism of Endocannabinoids. In: Onaivi, ES.; Sugiura, T.; Di Marzo, V., editors. Endocannabinoids. CRC Press; 2006. p. 177-214.

Takahashi KA, Castillo PE. The CB1 cannabinoid receptor mediates glutamatergic synaptic suppression in the hippocampus. Neuroscience. 2006

Thomas BF, Wei X, Martin BR. Characterization and autoradiographic localization of the cannabinoid binding site in rat brain using [3H]11-OH-delta 9-THC-DMH. J Pharmacol Exp Ther 1992;263:1383-1390. [PubMed: 1335065]

Thomas EA, Cravatt BF, Danielson PE, Gilula NB, Sutcliffe JG. Fatty acid amide hydrolase, the degradative enzyme for anandamide and oleamide, has selective distribution in neurons within the rat central nervous system. J Neurosci Res 1997;50:1047-1052. [PubMed: 9452020]

Toth A, Boczan J, Kedei N, Lizanecz E, Bagi Z, Papp Z, Edes I, Csiba L, Blumberg PM. Expression and distribution of vanilloid receptor 1 (TRPV1) in the adult rat brain. Brain Res Mol Brain Res 2005;135:162-168. [PubMed: 15857679]

Trettel J, Levine ES. Endocannabinoids mediate rapid retrograde signaling at interneuron right-arrow pyramidal neuron synapses of the neocortex. J Neurophysiol 2003;89:2334-2338. [PubMed: 12686587]

Tsou K, Brown S, Sanudo-Pena MC, Mackie K, Walker JM. Immunohistochemical distribution of cannabinoid CB1 receptors in the rat central nervous system. Neuroscience 1998a;83:393-411. [PubMed: 9460749]

Tsou K, Mackie K, Sanudo-Pena MC, Walker JM. Cannabinoid CB1 receptors are localized primarily on cholecystokinin-containing GABAergic interneurons in the rat hippocampal formation. Neuroscience 1999;93:969-975. [PubMed: 10473261]

Tsou K, Nogueron MI, Muthian S, Sanudo-Pena MC, Hillard CJ, Deutsch DG, Walker JM. Fatty acid amide hydrolase is located preferentially in large neurons in the rat central nervous system as revealed by immunohistochemistry. Neurosci Lett 1998b;254:137-140. [PubMed: 10214976]

Van der Stelt M, Veldhuis WB, Bar PR, Veldink GA, Vliegenthart JF, Nicolay K. Neuroprotection by Delta9-tetrahydrocannabinol, the main active compound in marijuana, against ouabain-induced in vivo excitotoxicity. J Neurosci 2001a;21:6475-6479. [PubMed: 11517236]

Van der Stelt M, Veldhuis WB, Maccarrone M, Bar PR, Nicolay K, Veldink GA, Di MV, Vliegenthart $\mathrm{JF}$. Acute neuronal injury, excitotoxicity, and the endocannabinoid system. Mol Neurobiol 2002;26:317-346. [PubMed: 12428763]

Van der Stelt M, Veldhuis WB, van Haaften GW, Fezza F, Bisogno T, Bar PR, Veldink GA, Vliegenthart JF, Di MV, Nicolay K. Exogenous anandamide protects rat brain against acute neuronal injury in vivo. J Neurosci 2001b;21:8765-8771. [PubMed: 11698588]

Van Sickle MD, Duncan M, Kingsley PJ, Mouihate A, Urbani P, Mackie K, Stella N, Makriyannis A, Piomelli D, Davison JS, Marnett LJ, Di Marzo V, Pittman QJ, Patel KD, Sharkey KA. Identification and functional characterization of brainstem cannabinoid CB2 receptors. Science 2005;310:329332. [PubMed: 16224028]

Varma N, Carlson GC, Ledent C, Alger BE. Metabotropic glutamate receptors drive the endocannabinoid system in hippocampus. J Neurosci 2001;21:RC188. [PubMed: 11734603]

Wallace MJ, Blair RE, Falenski KW, Martin BR, Delorenzo RJ. The endogenous cannabinoid system regulates seizure frequency and duration in a model of temporal lobe epilepsy. J Pharmacol Exp Ther 2003;307:129-137. [PubMed: 12954810]

Wallace MJ, Martin BR, Delorenzo RJ. Evidence for a physiological role of endocannabinoids in the modulation of seizure threshold and severity. Eur J Pharmacol 2002;452:295-301. [PubMed: 12359270]

Wallace MJ, Wiley JL, Martin BR, Delorenzo RJ. Assessment of the role of CB1 receptors in cannabinoid anticonvulsant effects. Eur J Pharmacol 2001;428:51-57. [PubMed: 11779037]

Wilkison DM, Pontzer NJ. The actions of THC on the intact hippocampus: a comparison of dentate and CA1 responses. Brain Res Bull 1987;19:63-67. [PubMed: 2820552]

Wilson RI, Kunos G, Nicoll RA. Presynaptic specificity of endocannabinoid signaling in the hippocampus. Neuron 2001;31:453-462. [PubMed: 11516401] 
Wilson RI, Nicoll RA. Endogenous cannabinoids mediate retrograde signalling at hippocampal synapses. Nature 2001;410:588-592. [PubMed: 11279497]

Wilson RI, Nicoll RA. Endocannabinoid signaling in the brain. Science 2002;296:678-682. [PubMed: 11976437]

Yanovsky Y, Mades S, Misgeld U. Retrograde signaling changes the venue of postsynaptic inhibition in rat substantia nigra. Neuroscience 2003;122:317-328. [PubMed: 14614899]

Yoshida T, Hashimoto K, Zimmer A, Maejima T, Araishi K, Kano M. The cannabinoid CB1 receptor mediates retrograde signals for depolarization-induced suppression of inhibition in cerebellar Purkinje cells. J Neurosci 2002;22:1690-1697. [PubMed: 11880498]

Yoshida T, Fukaya M, Uchigashima M, Miura E, Kamiya H, Kano M, Watanabe M. Localization of Diacylglycerol Lipase-\{alpha\} around Postsynaptic Spine Suggests Close Proximity between Production Site of an Endocannabinoid, 2-Arachidonoyl-glycerol, and Presynaptic Cannabinoid CB1 Receptor. J Neurosci 2006;26:4740-4751. [PubMed: 16672646]

Zhu PJ, Lovinger DM. Retrograde endocannabinoid signaling in a postsynaptic neuron/synaptic bouton preparation from basolateral amygdala. J Neurosci 2005;25:6199-6207. [PubMed: 15987949]

Zygmunt PM, Petersson J, Andersson DA, Chuang H, Sorgard M, Di Marzo V, Julius D, Hogestatt ED. Vanilloid receptors on sensory nerves mediate the vasodilator action of anandamide. Nature 1999;400:452-457. [PubMed: 10440374] 
A
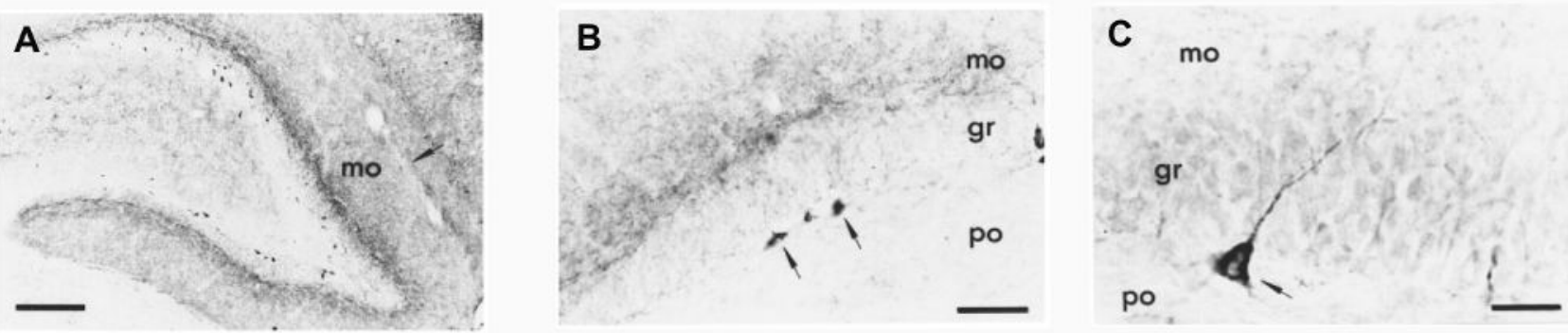

B
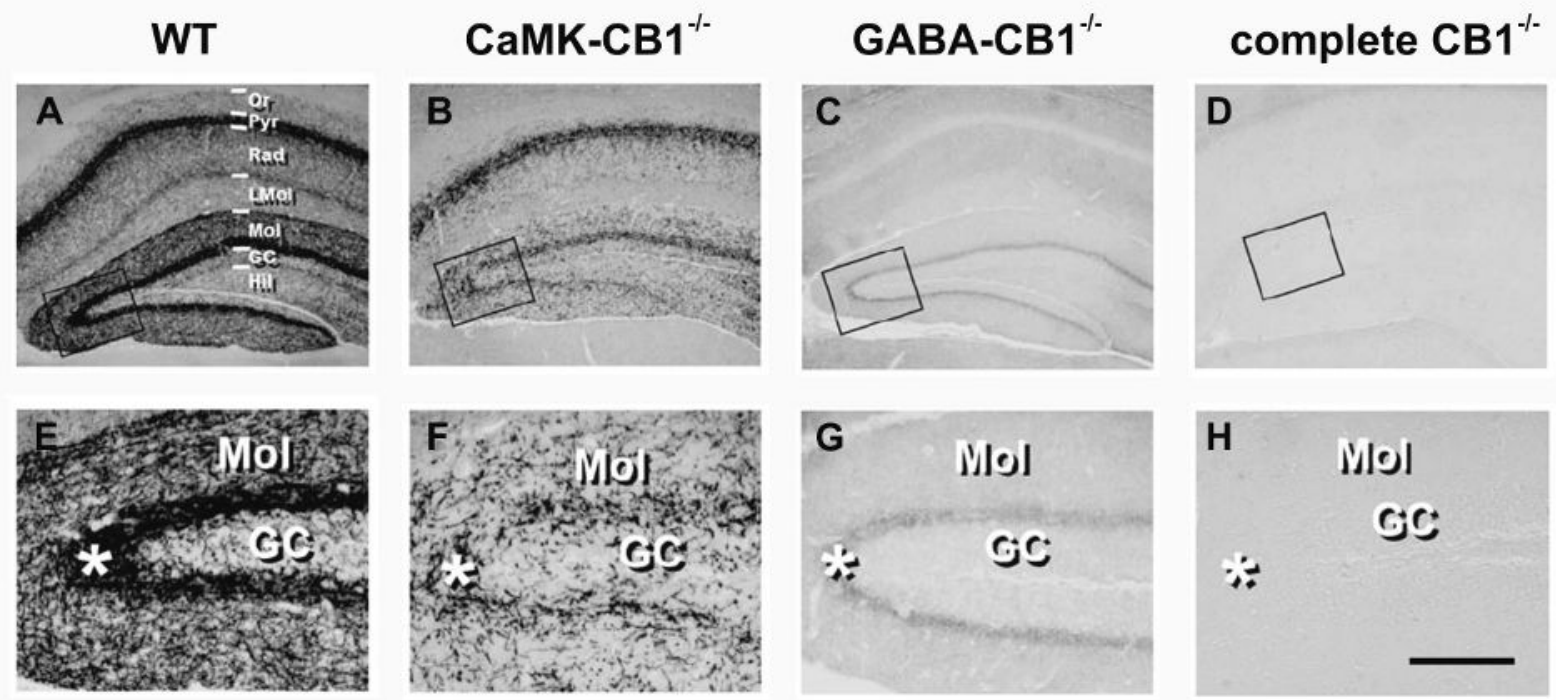

Figure 1. CB1 receptor expression in the dentate gyrus

$A_{A}$ ) An early study demonstrates intense immunoreactivity for CB1 receptors in the dentate gyrus, especially in the inner molecular layer (mo). $A_{B-C}$ ) Although dentate granule cells appear to be CB1 negative, there are many intensely stained neurons found at the base of the granule cell layer, with characteristic pyramidal morphology. Other intensely stained neurons were found in the hilus (not shown). Note that labeled cell bodies were generally absent in the molecular layer. Scale bars: $200 \mu \mathrm{m}, 50 \mu \mathrm{m}, 20 \mu \mathrm{m}$ in $\mathrm{A}_{\mathrm{A}}-\mathrm{A}_{\mathrm{C}}$ respectively. Reproduced with permission from Tsou et al., 1998a. B) A recent immunohistochemical analysis of CB1 receptor expression in wild type (WT), CaMK-CB1 $1^{-/}$, $\mathrm{GABA}_{-\mathrm{CB}} 1^{-/-}$, and complete $\mathrm{CB}^{-/-}$mice provided clear evidence of $\mathrm{CB} 1$ expression on glutamatergic terminals (as well as GABAergic terminals) in the inner molecular layer of the dentate gyrus. Areas indicated by black boxes in top row are shown in higher magnification in the bottom row. Scale bar in $\mathrm{H}$ is $\sim 100 \mu \mathrm{m}$. Reproduced with permission from Monory et al., 2006. 
A
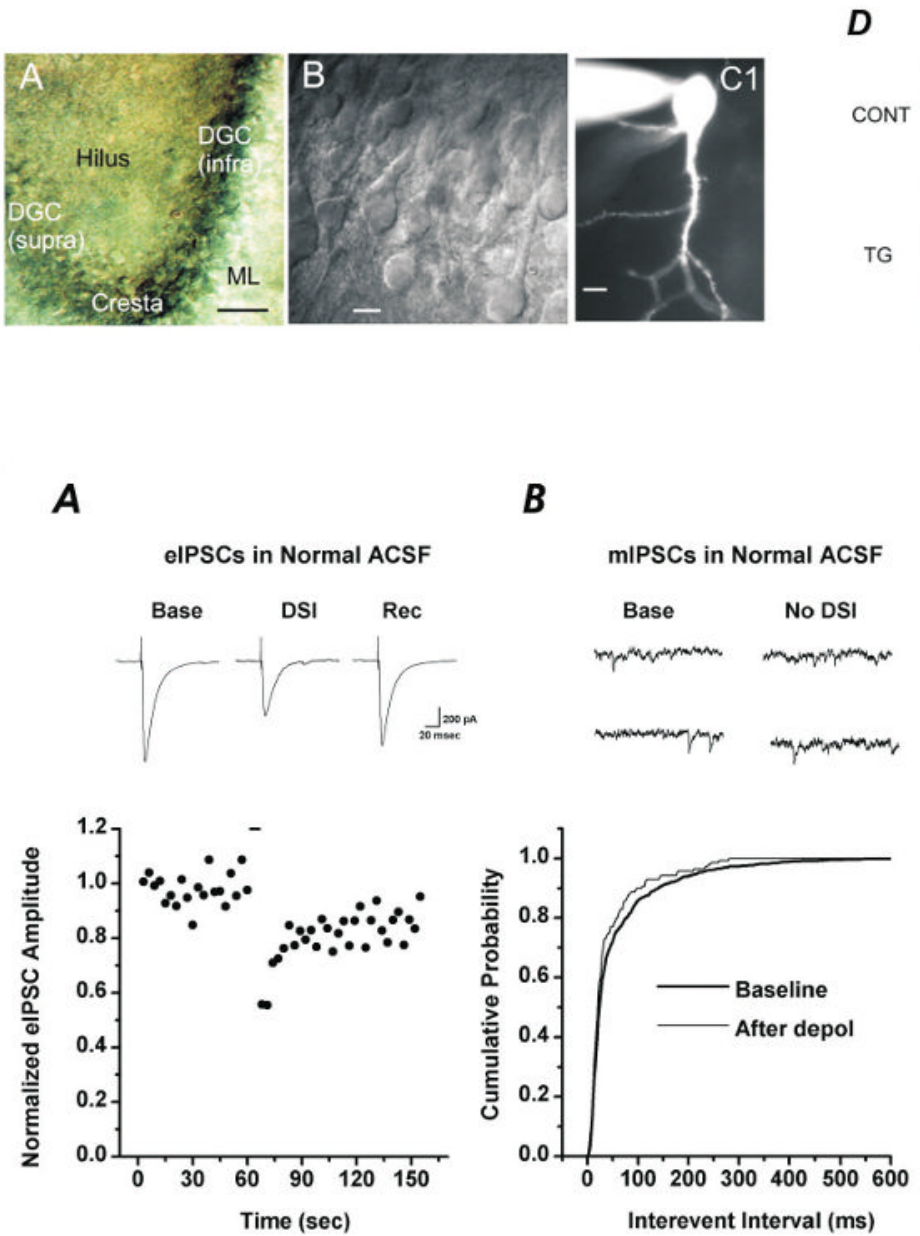

C
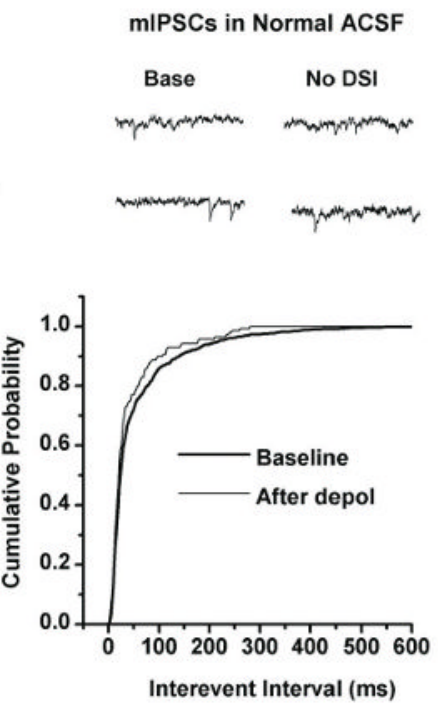

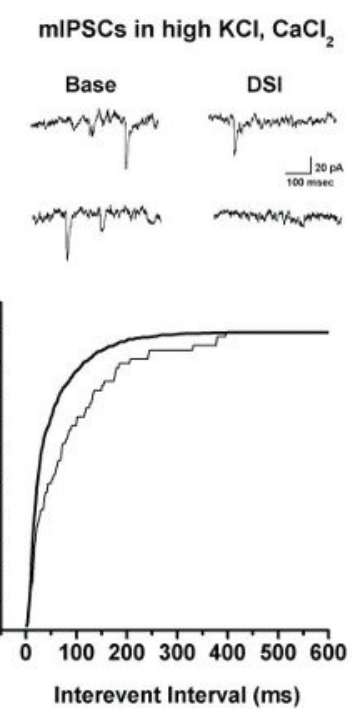

D

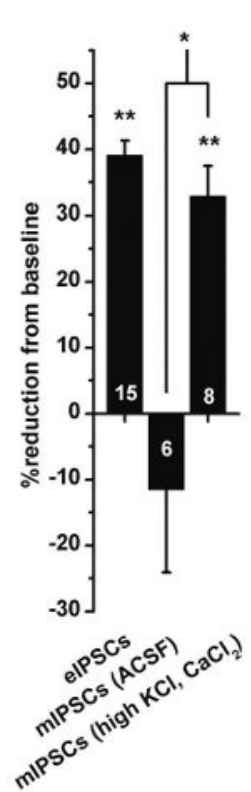

Figure 2. DSI in dentate granule cells and hilar mossy cells

$\left.A_{A}\right)$ Dentate gyrus of the hippocampal slice $($ scale, $50 \mu \mathrm{m}) . A_{B}$ ) Differential interference contrast image of dentate granule cells (scale, $10 \mu \mathrm{m}$ ). $\mathrm{A}_{\mathrm{C}}$ ) Single dentate granule cell filled visualized with fluorescence microscopy during whole cell recording (scale, $10 \mu \mathrm{m})$. $\mathrm{A}_{\mathrm{D}}$ ) DSI of eIPSCs (left, top) and sIPSCs (right, top) is observed in dentate granule cells. In both cases, magnitude of DSI is reduced by bath application of thapsigargin (TG, $2 \mu \mathrm{M}$, bottom). $\mathrm{A}_{\mathrm{E}}$ ) Thapsigargin also reduced the calcium transients produced by DSI-inducing depolarizing voltage steps. Reproduced with permission from Isokawa and Alger, 2005. B) Depolarization induced release of endogenous cannabinoids from hilar mossy cells preferentially inhibits calcium dependent exocytosis. DSI in of evoked IPSCs is apparent in an individual mossy cell. DSI of miniature IPSCs is absent in the same cell. Following bath application of $\mathrm{KCl}$ and $\mathrm{CaCl}_{2}$, DSI of mIPSCs becomes apparent. Summary data are presented in $\mathrm{B}_{\mathrm{D}}$, where numbers on the bars are n values. Reproduced with permission from Hofmann et al., 2006. 